\title{
Meat Quality of Goats Fed Hay, Sorghum Bagasse and Standard Diets
}

\author{
Adebamikale Olajide ${ }^{1}$, Edward Sismour ${ }^{1}$, Yixiang $\mathrm{Xu}^{1} \&$ Adnan Yousuf ${ }^{1}$ \\ ${ }^{1}$ Agricultural Research Station, Virginia State University, Petersburg, Virginia, USA \\ Correspondence: Adnan B. Yousuf, Agricultural Research Station, Virginia State University, Petersburg, Virginia \\ 23806, USA. Tel: 1-804-524-6795. Fax: 1-804-524-5186. E-mail: ayousuf@vsu.edu
}

Received: September 3, 2018

Accepted: October 27, $2018 \quad$ Online Published: December 15, 2018

doi:10.5539/jas.v11n1p1

URL: https://doi.org/10.5539/jas.v11n1p1

\begin{abstract}
A study was conducted to determine effects of feeding hay (HAY), sorghum bagasse (SOB) and standard Virginia State University diet for small ruminants (STA) on the physiochemical and fatty acid profile of goat meat. Sixteen Myotonic (Tennessee Stiff Leg) male goats with body weight (BW) of 21.6 $\pm 3.0 \mathrm{~kg}$ were divided into three groups and subjected to one of three dietary treatments for 76 days. At the end of the feeding trial, the animals were harvested and the Longissimus thoracis et lumborum (LTL) muscle samples analyzed to evaluate meat quality. There was no difference $(\mathrm{P}>0.05)$ in initial $\mathrm{pH}(\mathrm{pH} 0)$ measured at 45 min post-harvest and ultimate $\mathrm{pH}(\mathrm{pHu})$ measured at $72 \mathrm{~h}$ postmortem. HAY and $\mathrm{SOB}$ diets did not affect $(\mathrm{P}>0.05)$ water binding capacity (WBC), instrumental meat color ( $\mathrm{L}^{*}$ (lightness), $\mathrm{a}^{*}$ (redness), $\mathrm{b}^{*}$ (yellowness), $\mathrm{C}^{*}$ (Chroma), and $\mathrm{H}^{*}$ (Hue Angle), and tenderness, as measured by Warner-Bratzler shear force (WBSF). Chemical composition and fatty acid profile were also not influenced by the treatments $(\mathrm{P}>0.05)$. The findings of this study support the use of HAY and SOB as supplemental diet during times of feed shortages without impacting major meat quality characteristics in goats.
\end{abstract}

Keywords: goats, diets, meat quality, fatty acids

\section{Introduction}

Goat meat (Chevon) is regarded as a lean red meat, with favorable nutritive characteristics (Webb, 2014; Webb, et al., 2005). The leanness of goat meat can be attributed to the ability of goats to deposit greater quantities of fat internally in the abdominal cavity and less in subcutaneous and intramuscular fat depots (Goetsch et al., 2011). The low subcutaneous fat cover in goat carcasses exposes it to moisture loss during chilling causing cold shortening resulting in less tender meat (Kannan et al., 2014). Meat tenderness is also influenced by age. Meat from older goats is recognized to have higher levels of collagen in the muscles, which lowers tenderness (Tshabalala et al., 2003). Chevon is considered to be leaner than lamb when obtained from animals harvested at a similar age, and it is perceived as being less juicy due to a lower intramuscular fat content (Sheridan et al., 2003b).

Goat meat quality is the product of inherent features (species, breed, gender and, age), environmental factors (season, diet) and the ante-mortem experiences of the animal and the early post-mortem treatments during processing (Hutchison et al., 2012). Post-mortem pH decline, which is a direct consequence of muscle glycogen concentrations and stress levels preceding slaughter also influences the color, water holding capacity, tenderness and shelf life of meat (Wiklund et al., 2004). Post-mortem $\mathrm{pH}$ values dictate the effectiveness of the enzymatic tenderization process, where increases in ultimate $\mathrm{pH}(\mathrm{pHu})$ values from 5.5-6.0 generally manifest in decreased tenderness. Abnormally high ultimate $\mathrm{pH}$ values can result in dark, firm and dry meat if harvested from animals under stressful conditions (Daszkiewicz et al., 2015).

Goat meat characteristics perceived by the senses (color, amount of visible water, and amount of fat and textural appearance) and palatability attributes (tenderness and flavor) play important role in the consumer's approval of meat quality (Brewer et al., 2001). The color of meat is particularly important as this is the first quality sign observed by the consumer at the point of sale, often being used as an indicator of product freshness and acceptability (Font-i-Furnols \& Guerrero, 2014). Color is primarily attributed to the quantity and quality of the myoglobin pigment in the meat, as well as its susceptibility to be oxidized to metmyoglobin (Mancini \& Hunt, 2005). Meat products are generally expected to be bright pink or red in color, with those that are too pale or too dark frequently being not preferred by consumers. Mancini and Hunt (2005), recognized tenderness as an 
important palatability attribute of meat that determines the consumer's consumption quality. Tenderness is affected by contractile protein integrity, sarcomere length, connective tissue content, endogenous protease activity, and the levels of intramuscular fat (Juárez et al., 2012).

Fatty acid composition of ruminant's meat is generally less affected by dietary lipid composition than that from non-ruminants (Rhee, 1992). Hydrogenation of dietary lipids by the rumen microbes causes an inequality between dietary FA composition and lean FA composition (Byers \& Schelling, 1993). Fatty acid composition of the diet can alter FA composition of lean meat, with lean of goats on pasture being more saturated than lean of goats fed a grain-based diet. Different levels of concentrate in the diet may influence FA composition of goat meat, potentially modifying the health benefit of this alternative protein source. Meat from goats has fewer calories, a lower fat content and a reduced proportion of saturated fatty acids compared to lamb meat and beef (Babiker et al., 1990; Abubakr et al., 2015; Silva et al., 2016). Therefore, consumers consider goat meat as healthy (USDA, 1990; Parodi, 2016), and its consumption has been increasing. While a great deal has been done to measure and quantify the physical and chemical meat quality attributes of domestic livestock species (Devine et al., 2006; Kim et al., 2010; Muchenje et al., 2009), there is limited work on the effects of feeding sorghum bagasse based diet on these attributes on goat meat quality. The aim of this study was thus to evaluate the instrumental meat quality and chemical composition including fatty acid profile of meat from goats fed on concentrate, hay and agricultural byproduct based diets.

\section{Materials and Methods}

\subsection{Location}

The study was carried out in Virginia State University small ruminant research facility at Randolph Farm. The protocol for the experiment was approved by the Virginia State University Animal Care and Use Committee. All experimental animals received standard management practices approved by the University.

\subsection{Animal, Feeds and Management}

Sixteen Myotonic intact male goats similar in age and with an average initial body weight (BW) of $21.6 \pm 3.0 \mathrm{~kg}$ were selected from the VSU Small Ruminant Research herd and used in the study that lasted 75 days. The animals were assigned to individual indoor feeding pens $\left(8^{\prime} \times 10^{\prime}\right)$ with cement flooring covered with sawdust. The pens were equipped with nipple waterers and portable feed bunks and trace mineral salt blocks were available at all times. The selected goats were acclimatized for three weeks to the indoor facility and the experimental feed (Table 1).

The three diets fed consisted of Virginia State University Standard diet (STA) for sheep and goats, and the second and third diets where half the standard diet is replaced by local hay (HAY) and sorghum bagasse (SOB). The Ingredient composition of the experimental diets is shown in Table 1.

Table 1. Ingredient composition (\%) of experimental diets as fed

\begin{tabular}{llll}
\hline Item & STA & HAY & SOB \\
\hline Sorghum bagasse & - & - & 50.0 \\
Hay & - & 50.0 & - \\
Alfalfa Pellet & 50.0 & - & - \\
Corn & 20.0 & 20.0 & 20.0 \\
Soybean & 18.0 & 18.0 & 18.0 \\
Wheat bran & 10.0 & 10.0 & 10.0 \\
Molasses & 2.0 & 2.0 & 2.0 \\
Salt & 0.5 & 0.5 & 0.5 \\
Total & 100.0 & 100.0 & 100.0 \\
\hline
\end{tabular}

Note. STA = Standard VSU Diet; HAY = Local Hay; $\mathrm{SOB}=$ Sorghum bagasse.

\subsection{Slaughter and Post-slaughter Procedure}

At the end of the experiment, four goats from each treatment were randomly selected for slaughter after being fasted overnight. The selected goats were transported to a commercial abattoir and humanely harvested using standard procedures. Goats were electrically stunned before exsanguinated, and dressed according to industry-accepted procedures. After measurements on hot carcass, it was chilled overnight at $4{ }^{\circ} \mathrm{C}$ and cold 
carcass weight determined the next morning. The carcasses were split in two through the middle of the vertebrate into left and right halves. The LTL muscle from the left side of the carcass was sampled for instrumental meat quality analysis. Sample were also collected from the LTL muscle for use in estimating body composition. All visible cover fat was separated from the meat surface, wrapped in aluminum foil and stored frozen at $-20{ }^{\circ} \mathrm{C}$ for chemical composition and fatty acid profile analyses.

\subsection{Meat $p H$}

The initial $\mathrm{pH}(\mathrm{pH} 0)$ was measured within the first 45 min of slaughtering warm carcass, by inserting into the meat a temperature compensated combination glass calomel electrode connected to a portable $\mathrm{pH}$-meter (Oakton $\mathrm{pH} 700$ with probes and NIST calibration). The ultimate $\mathrm{pH}(\mathrm{pHu})$ was determined $72 \mathrm{~h}$ postmortem on ground and minced LTL muscle sample during determination of water binding capacity using Coning table top $\mathrm{pH}$ meter (Corning Inc. NY). The $\mathrm{pH}$ meter was calibrated at the beginning using $\mathrm{pH} 4.6$ and 7.0 buffers.

\subsection{Water Binding Capacity}

Water binding capacity of meat was determined using the method of Wardlaw, et al. (1973) with slight modification. The meat sample ( $30 \mathrm{~g}$ ) was finely minced, $45 \mathrm{ml}$ of de ionized water added to it and the content mixed using magnetic stirrer for 2 minutes. Meat slurry was held for 15 minutes at $4{ }^{\circ} \mathrm{C}$ to equilibrate and again shaken for one minute on the mechanical shaker and centrifuged for 15 minutes at $5000 \mathrm{rpm}$ in refrigerated centrifuge at $4{ }^{\circ} \mathrm{C}$. The supernatant volume was measured and the difference between the added and decanted solution was expressed as percent of initial weight $(30 \mathrm{gm})$ of the meat samples as measurement of water holding capacity.

\subsection{Tenderness (Warner-Bratzler Shear Force)}

The shear force was determined on LTL muscle samples measured using a Warner-Bratzler Shearing instrument (TA.XT- plus Texture Analyzer) that measured the shear force with a Meullenet-Owens Razor Shear (MORS) blade. The longitudinal axis of the core was parallel to the direction of the muscle fibers to ensure the sample cores were sheared at right angles to the fiber axis.

\subsection{Meat Color}

The LTL muscle color measures were recorded $72 \mathrm{~h}$ post-mortem on a freshly cut surface of the LTL muscle. Each sample was allowed to bloom for $45 \mathrm{~min}$ before color was measured using a Chroma meter, (CR-400/410) following the CIE (CIE, 1978) system which measures $\mathrm{L}^{*}, \mathrm{a}^{*}, \mathrm{~b}^{*}$ values. $\mathrm{L}^{*}$, the index related to lightness ( $\mathrm{L}^{*}=$ 0 black, 100 white); $a^{*}$ (redness), the index ranging from green $(-)$ to red $(+)$; and $b^{*}$ (yellowness), the index ranging from blue $(-)$ to yellow $(+)$. Additional reflectance indices, Hue angle $\mathrm{H}^{*}$, a measurement where a vector radiates into the red-yellow quadrant, and the color saturation index Chroma $\mathrm{C}^{*}$, were calculated according to the formulas: Chroma $=\left(\mathrm{a}^{*^{2}}+\mathrm{b}^{* 2}\right)^{0.5}$ and Hue Angle $=\tan ^{-1} *\left(\mathrm{~b}^{*} / \mathrm{a}^{*}\right)$.

\subsection{Chemical Composition}

Samples of LTL muscle were subjected to proximate analyses following the standard methods of AOAC (2002). Dry matter (DM) was determined by oven drying in a forced air oven at $105^{\circ} \mathrm{C}$ for $24 \mathrm{~h}$. The $\mathrm{N}$ content of LTL muscle was determined using a combustion method with Vario Max CN (Elementar Americas, Inc., Mt. Laurel, NJ, USA) and was calculated by multiplying nitrogen concentration by a conversion factor of 6.25 , while ether extract (EE) was determined in petroleum ether using a Soxhlet apparatus. The ash content was determined by ashing the samples in a muffle furnace at $600{ }^{\circ} \mathrm{C}$ for $5 \mathrm{~h}$. All proximate analyses were done on triplicate LTL muscle samples.

\subsection{Fatty Acid Profile}

To determine the fatty acid profile in LTL muscle, lipid samples previously extracted from the LTL were converted to fatty acid methyl esters (FAME). The oil was extracted in three rounds from $1 \mathrm{~g}$ ground freeze dried goat meat at room temperature by homogenization and centrifugation. The three extractions were pooled. The lipid layer was separated via the standard hexane: methanol method. Percent oil was calculated on a $\mathrm{g} / 100 \mathrm{~g}$ dry matter basis, vacuum dried and stored under $\mathrm{N}_{2}$ at $-10^{\circ} \mathrm{C}$ until further analysis.

The FAME preparation and analysis was conducted according to a previously published method (Bhardwaj \& Hamama, 2012). In brief, samples were vortexed with a $2 \mathrm{ml} \mathrm{1/100} \mathrm{sulfuric} \mathrm{acid} \mathrm{methanol} \mathrm{mixture} \mathrm{with} \mathrm{teflon}$ derived boiling chips. Samples were then heated at $90{ }^{\circ} \mathrm{C}$ until $0.5 \mathrm{ml}$ residue was evident and allowed to cool to room temperature, to which $1 \mathrm{ml}$ of hexane and distilled water was sequentially added. After vortexing, the upper hexane layer (FAME) was dried over anhydrous sodium sulfate. The hexane phase containing FAME was stored under $\mathrm{N}_{2}$ at $0{ }^{\circ} \mathrm{C}$ and analyzed by gas chromatography (Vista $6000 \mathrm{GC}$ ). Peaks were identified using 
FAME retention and internal standards (C17:0) for quantification. Fatty acid concentration was calculated as a percentage $(\mathrm{w} / \mathrm{w})$ of total fatty acids.

\subsection{Statistical Analysis}

The data were subjected to one-way analysis of variance using the GLM procedure of SAS (SAS, 2013) and the differences between means were compared using Duncan multiple range test, with significant differences being declared at $\mathrm{P}<0.05$.

\section{Results}

\subsection{Meat pH, Water Binding Capacity and Shear Force}

The initial $\mathrm{pH}(\mathrm{pH} 0)$ on warm carcass and ultimate $\mathrm{pHu} 24 \mathrm{~h}$ after harvest for the LTL muscle of goats on the three dietary treatments are shown in Table 2. There was no significant difference $(\mathrm{P}>0.05)$ in $\mathrm{pH} 0$ of the LTL muscle from goats fed on the three diets. The lowest $\mathrm{pHu}$ of LTL was noted in goats fed the SOB diet.

Table 2. $\mathrm{pH}$, water binding capacity and Warner-Bratzler shear force values of goat meat fed the three experimental diets

\begin{tabular}{lllll}
\hline & \multicolumn{3}{c}{ Diets } & \multirow{2}{*}{ SE } \\
\cline { 2 - 4 } & STA & HAY & SOB & 0.12 \\
$\mathrm{pH} 0$ & 6.80 & 6.62 & 6.69 & 0.14 \\
$\mathrm{pHu}$ & 5.75 & 5.59 & 5.43 & 0.02 \\
WBC $(\%)$ & 22.15 & 22.08 & 22.79 & 0.30 \\
WBSF $\left(\mathrm{kgf} / \mathrm{cm}^{2}\right)$ & $2.06^{\mathrm{b}}$ & $2.15^{\mathrm{a}}$ & $2.43^{\mathrm{a}}$ & \\
\hline
\end{tabular}

Note. $\mathrm{pHO}=$ initial $\mathrm{pH} ; \mathrm{pHu}=$ ultimate $\mathrm{pH}$; $\mathrm{STA}=$ Standard diet; $\mathrm{HAY}=$ hay based diet; $\mathrm{SOB}=$ sorghum bagasse based diet; SEM $=$ Standard error of mean. $\mathrm{WBC}=$ Water binding capacity; WBSF $=$ Warner-Bratzler shear force; $a, b$, Means in the same row with different superscripts are significantly different $(\mathrm{P}<0.05)$.

Water binding capacity of the LTL muscle of goats on the three diets is shown in Table 2. There was no significant difference $(\mathrm{P}>0.05)$ in WBC of the LTL muscle from goats fed the three experimental diets.

Tenderness is a component of meat quality that sways consumers' eating satisfaction. It is inversely related to the Warner-Bratzler shear force. The WBSF results are shown in Table 2. The WBSF values for the LTL muscle from goats fed the HAY and SOB diets were similar whereas the WBSF of LTL from goats on STA diet showed lower $(\mathrm{P}<0.05)$ shear force values compared to goats on the other two diets.

\subsection{Meat Color}

Meat color of the LTL muscle of goats fed the three diets is shown in Table 3. Dietary source showed significant effect $(\mathrm{P}<0.05)$ for the color coordinates lightness $\left(\mathrm{L}^{*}\right)$, redness $\left(\mathrm{a}^{*}\right)$, yellowness $\left(\mathrm{b}^{*}\right)$, and Chroma $\left(\mathrm{C}^{*}\right)$ values. The Hue Angle $\left(\mathrm{H}^{*}\right)$ was not different $(\mathrm{P}>0.05)$ among the LTL muscle of goats on the three diets.

Table 3. Color values of goat meat fed the three experimental diets

\begin{tabular}{lllll}
\hline \multirow{2}{*}{ Item } & \multicolumn{3}{c}{ Diets } & SE \\
\cline { 2 - 5 } & STA & HAY & SOB & 0.73 \\
\hline $\mathrm{L}^{*}$ & $36.5^{\mathrm{b}}$ & $40.0^{\mathrm{a}}$ & $39.7^{\mathrm{a}}$ & 0.54 \\
$\mathrm{a}^{*}$ & $17.8^{\mathrm{b}}$ & $20.2^{\mathrm{a}}$ & $19.0^{\mathrm{a}}$ & 0.41 \\
$\mathrm{~b}^{*}$ & $8.1^{\mathrm{b}}$ & $9.7^{\mathrm{a}}$ & $9.0^{\mathrm{a}}$ & 0.64 \\
$\mathrm{C}^{*}$ & $19.8^{\mathrm{b}}$ & $22.4^{\mathrm{a}}$ & $21.0^{\mathrm{a}}$ & 0.65 \\
$\mathrm{H}^{*}$ & 23.8 & 25.7 & 25.4 & 0.4 \\
\hline
\end{tabular}

Note. $\mathrm{L}^{*}=$ Lightness; $\mathrm{a}^{*}=$ redness; $\mathrm{b}^{*}=$ yellowness; $\mathrm{C}^{*}=$ Chroma; $\mathrm{H}^{*}=$ Hue Angle; STA = Standard diet; HAY $=$ hay based diet; $\mathrm{SOB}=$ sorghum bagasse based diet. $\mathrm{a}, \mathrm{b}$, Means in the same row with different superscripts are significantly different $(\mathrm{P}<0.05)$. 


\subsection{Meat Proximate Composition and Fatty Acid Profile}

The proximate composition analyses of LTL is shown in Table 4. The LTL samples did not differ $(P>0.05)$ in $\mathrm{DM}, \mathrm{OM}, \mathrm{CP}$, and ash contents (Table 4). The fat content of the meat of goats on SOB diet, however, was lower $(\mathrm{P}<0.05)$ than those on STA and HAY diets.

Table 4. Proximate composition of goat meat fed the three experimental diets

\begin{tabular}{lllll}
\hline \multirow{2}{*}{ Item } & \multicolumn{3}{c}{ Diets } & \multirow{2}{*}{ SE } \\
\cline { 2 - 3 } & STA & HAY & SOB & 0.15 \\
DM & -1.50 & 23.20 & 23.30 & 0.28 \\
OM & 23.50 & 94.96 & 95.48 & 0.23 \\
Protein & 95.47 & 13.41 & 12.93 & 1.18 \\
Fat & 13.73 & $6.33^{\mathrm{a}}$ & $3.85^{\mathrm{b}}$ & 0.28 \\
Ash & $8.41^{\mathrm{a}}$ & 5.04 & 4.52 & $\mathrm{~g}$ \\
\hline
\end{tabular}

Note. $\mathrm{DM}=$ Dry matter; $\mathrm{OM}=$ Organic matter; $\mathrm{STA}=$ Standard diet; HAY $=$ hay based diet; $\mathrm{SOB}=$ sorghum bagasse based diet. a, b, Means in the same row with different superscripts are significantly different $(\mathrm{P}<0.05)$.

Table 5 shows fatty acid profiles of goat LTL muscle fed the experimental diets. The major fatty acids in LTL samples were C16:0, C18:0, C18:1, and C18:2. The composition of fatty acids (g/100 g fat) in the LTL did not change $(\mathrm{P}>0.05$; Table 5) the saturated fatty acids (SFAs), monounsaturated fatty acids (MUFAs), and all polyunsaturated fatty acids (PUFAs) except C20:4 and C20:5. The sum the saturated fatty acid ( $\Sigma$ SFA), mono

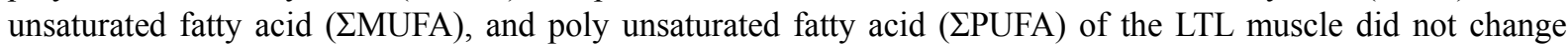
with the $\operatorname{diet}(\mathrm{P}>0.05)$. However, there were decreasing trends in $\mathrm{C} 10: 0(\mathrm{P}=0.078), \mathrm{C} 22: 0(\mathrm{P}=0.058)$ and $\mathrm{C} 18: 2 \mathrm{n}-6(\mathrm{P}=0.090)$ and an increasing trend in MUFA C16:1 $(\mathrm{P}=0.074)$. 
Table 5. Fatty acid profile of Longissimus dorsi et lumbarum muscle of goats fed the experimental diets

\begin{tabular}{|c|c|c|c|c|c|}
\hline \multirow{2}{*}{ Fatty acid } & \multicolumn{3}{|c|}{ Diet } & \multirow{2}{*}{ SE } & \multirow{2}{*}{$\mathrm{P}$ value } \\
\hline & HAY & SOB & STA & & \\
\hline C10:0 & 0.50 & 0.31 & 0.22 & 0.10 & 0.21 \\
\hline C12:0 & 0.66 & 0.42 & 0.27 & 0.13 & 0.17 \\
\hline C12:1 & 1.22 & 1.11 & 0.72 & 0.21 & 0.26 \\
\hline C14:0 & 1.49 & 1.22 & 1.13 & 0.21 & 0.49 \\
\hline $\mathrm{C} 14: 1$ & 0.91 & 0.83 & 0.46 & 0.14 & 0.11 \\
\hline C15:0 & 1.33 & 0.94 & 0.82 & 0.17 & 0.13 \\
\hline C15:1 & 0.34 & 0.29 & 0.17 & 0.05 & 0.10 \\
\hline C16:0 & 18.11 & 12.55 & 19.94 & 0.95 & 0.23 \\
\hline C16:1 & 1.05 & 1.17 & 1.01 & 0.26 & 0.90 \\
\hline C17:0 & 3.05 & 3.18 & 2.91 & 0.63 & 0.95 \\
\hline $\mathrm{C} 17: 1$ & 0.87 & 0.69 & 0.46 & 0.13 & 0.16 \\
\hline C18:0 & 12.82 & 11.97 & 14.07 & 1.00 & 0.37 \\
\hline C18:1 & 24.63 & 24.68 & 30.77 & 2.02 & 0.10 \\
\hline C18:2 & 6.63 & 8.04 & 7.36 & 1.14 & 0.69 \\
\hline C18:3 & 1.29 & 1.78 & 1.76 & 0.25 & 0.35 \\
\hline C20:0 & 0.74 & 0.44 & 0.36 & 0.11 & 0.07 \\
\hline C20:1 & 0.93 & 0.55 & 0.51 & 0.17 & 0.23 \\
\hline C20:2 & 0.49 & 0.72 & 0.46 & 0.08 & 0.10 \\
\hline $\mathrm{C} 20: 3$ & 0.41 & 0.37 & 0.29 & 0.13 & 0.78 \\
\hline C20:4 & $0.62^{\mathrm{a}}$ & $0.48^{\mathrm{b}}$ & $0.25^{\mathrm{c}}$ & 0.08 & 0.04 \\
\hline C20:5 & $0.62^{\mathrm{b}}$ & $1.13^{\mathrm{a}}$ & $1.28^{\mathrm{a}}$ & 0.13 & 0.01 \\
\hline $\mathrm{C} 22: 5$ & 0.93 & 1.64 & 1.63 & 0.25 & 0.12 \\
\hline \multicolumn{6}{|l|}{ Summary } \\
\hline$\Sigma \mathrm{SFA}$ & 38.70 & 36.08 & 39.72 & 1.59 & 0.30 \\
\hline$\Sigma$ MUFA & 29.96 & 29.33 & 34.12 & 1.64 & 0.13 \\
\hline$\Sigma$ PUFA & 10.99 & 14.16 & 13.03 & 1.48 & 0.35 \\
\hline \multicolumn{6}{|l|}{ Ratio } \\
\hline PUFA:SFA & 0.28 & 0.39 & 0.33 & 0.04 & 0.23 \\
\hline MUFA:PUFA & 2.81 & 2.17 & 2.67 & 0.26 & 0.25 \\
\hline
\end{tabular}

Note. $\mathrm{STA}=$ Standard diet; $\mathrm{HAY}=$ hay based diet; $\mathrm{SOB}=$ sorghum bagasse based diet; $\Sigma \mathrm{SFA}=$ Total saturated fatty acid; $\Sigma$ MUFA = Total mono unsaturated fatty acid; $\Sigma$ PUFA = Total poly unsaturated fatty acid.

\section{Discussion}

Ultimate $\mathrm{pH}$ of meat is responsive to muscle glycogen stores at slaughter and to the cooling rate of meat (Geay et al., 2001). The pHu is important to meat due to its effect on shelf life, color and quality of meat. As expected the $\mathrm{pHu}$ values measured $72 \mathrm{~h}$ postmortem were lower than the $\mathrm{pH} 0$ values. In the present study, $\mathrm{pHu}$ for LTL from STA (5.75) diet was similar $(\mathrm{P}>0.05)$ to the other two diet $(\mathrm{HAY}=5.59$ and $\mathrm{SOB}=5.43)$ groups. The $\mathrm{pHu}$ did not change because all animals were subjected to the same period of pre-slaughter fasting (a determining factor in the concentration of glycogen stores) and the same post slaughter procedures (Pereira et al., 2016; Silva et al., 2016).

Water binding/holding values and chemical composition from raw and cooked meat are not the same. The values from raw meat enable to predict the management situation of animal till slaughtering whereas values from cooking of meat are used to achieve a palatable and safe product. There was no effect of WBC (\%) on LTL of goats on the three diets $(\mathrm{STA}=22.15$; HAY $=22.08$; and $\mathrm{SOB}=22.79)$. There was no difference in $\mathrm{pHu}$ which may also explain the lack of difference in WBC.

The first assessment of quality of red meat by consumers is based on its color. Meat color is linked to both perception and real values (Holman et al., 2015). In the present study significant differences were found in the CIE L*(lightness), a* (redness) and $b^{*}$ (yellowness) values of the LTL from goats fed on the three experimental diets. The visual appearance of fresh meat is based on color, and water-holding capacity (Anderson et al., 2005). Changes in meat color are closely associated with lipid and pigment oxidation, as well as with microbial load (Granti et al., 2001). The pale appearance (higher $\mathrm{L}^{*}$ ) seen in the LTL muscle from goats on HAY and SOB diets 
could be attributed to the effect of high $\mathrm{pHu}$ values. Muscles from the animals on the STA diet were also expected to have a pale appearance but this was however not the case. The $\mathrm{a}^{*}$ (redness) value of the LTL in goats fed the STA diets was lower $(\mathrm{P}<0.05)$ than that from the HAY and SOB fed goats. The difference in Chroma $\left(\mathrm{C}^{*}\right)$ values for the muscles of all groups can be attributed to the electrical stunning. The passage of electricity through muscles in the form of electrical stimulation predisposes them to earlier discoloration (Ledward, 2006; van Laack \& Smulders, 1990; Wiklund et al., 2001).

Warner-Bratzler shear force is inversely related to tenderness. In this study, WBSF $\left(\mathrm{kgf} / \mathrm{cm}^{2}\right)$ or tenderness of LTL muscle of goats fed the HAY (2.15) and SOB (2.43) diets was less tender than that of the STA diet (2.06). Shear force values of LTL of goats below $4 \mathrm{kgf} / \mathrm{cm}^{2}$ is classified as tender (Perry et al., 2001; Geesink et al., 2011). In this regard, LTL muscles from the goats on the experimental diets in this study can generally be classified as being tender as all values were well below $4 \mathrm{kgf} / \mathrm{cm}^{2}$. Bond et al. (2004) reported that stress before slaughter has no significant effect on shear force values although shear force values tend to decrease with ageing. Similarly, Vergara et al. (2005) found no significant difference between the shear force of electrically stunned and non-stunned lambs after being aged for 7 days. Similar results have been reported previously (Vergara et al., 2000; Linares et al., 2008). The low shear force values obtained could principally be due to the effect of the young age of the goats.

Meat chemical analyses revealed no significant effect on moisture, protein and ash content, in the proximate composition analyses of LTL of goats fed the three diets. Fat content of LTL was however lower in the group of goats fed on SOB (3.85\%) compared to those on STA $(8.41 \%)$ and HAY (6.33\%) diets. In general, proximate composition of muscle in ruminant animals is influenced by diet and breed, as well as age and gender (Wood et al., 2003). Development of muscle depends on nutrient composition and utilization; therefore, the energy contents of the diet might partially explain the difference in chemical composition of muscle (Wood et al., 2003). In the present study, meat goats were offered very similar diet. Kannan et al. (2006) reported that meat parameters are influenced by dietary protein and available energy levels. The diets in this study appear to provide high levels of available protein which would have minimized any differences in meat proximate analyses.

The 16:0, 18:0, 18:1 and 18:2 were primary the FA comprising 78.5\% of the total FA in LTL (Table 7). Webb et al. (2005) reported similar FAs constituted the primary FA in longissimus muscle tissue. Fraser et al. (2004) reported that 18:1, 16:0 and 18:0 were the majority of FA in LTL muscle. Oleic acid (18:1 cis-9) and 18:0 were reported (Rhee et al., 2000) as the major constituent of Inter muscular (IMF) in goats. The majority FA in MUFA included 16:1 (palmitoleic) and 18:1, while the majority FA in PUFA were 18:2, 18:3 (linoleic), and 20:4 (arachidonic). Solaiman et al. (2011) reported that 18:1, 16:0, and 18:0 were the prominent FA in LTL muscle. In Boer goat, major FA in SFA were 16:0 and 18:0; levels were similar to the present study. These authors also reported that as carcass weight increased, 14:0 content tended to increase; 16:1 and heptadecenoic acids (both MUFA) were not affected. Kosulwat et al. (2003) reported that as lamb carcass fatness increased, the proportion of 14:0 increased and 18:0 decreased. No differences in 14:0, 14:1 and 18:0 were observed when goats were fed the experimental diets STA, HAY or SOB. The LTL from the HAY and SOB fed goats had higher C20:4 compared to those fed on STA diet.

\section{Conclusions}

The inclusion of HAY and SOB in the diet of meat goats neither altered the physicochemical composition of goat meat, nor increased the content of an undesirable saturated fatty acids. Based on this global evaluation, the level of inclusion of HAY and SOB as a maintenance diet during feed shortage is recommended, as there were no negative effects and the dietary cost would be expected to be lower at this inclusion level of hay and sorghum bagasse. Overall, the fatty acid profile is not adversely affected. The goat meat derived from these diets could be acceptable low-fat, red meat option with high desirable fatty acids.

\section{Acknowledgements}

Authors are thankful to Virginia State University and US Department of Agriculture (NIFA/Evans-Allen Program) for supporting this research with financial and physical resources. Authors also thank Dr. Guo-Liang Jiang and Mr. Ruddy Grammer (VSU) for providing the soybean straw and the corn stover.

\section{References}

Abubakr, A., Alimon, A. R., Yaakub, H., Abdullah, N., \& Ivan, M. (2015). Effect of feeding palm oil by-products based diets on muscle fatty acid composition in goats. PLoS One, 10, 1-12. https://doi.org/10.1371/journal. pone.0119756 
Andersen, H. A., Oksbjerg, N., Young, J. F., \& Therkildsen, M. (2005). Feeding and meat quality-A future approach. Meat Science, 70, 543-554. https://doi.org/10.1016/j.meatsci.2004.07.015

AOAC, (2002). Official methods of analysis (17th ed., 2nd revision). Gaithersburg, MD, USA.

Babiker, S. A., El Khider, I. A., \& Shafie, S. A. (1990). Chemical composition and quality attributes of goat meat and lamb. Meat Sci., 28, 273-277. https://doi.org/10.1016/0309-1740(90)90041-4

Bhardwaj, H. L., \& Hamama, A. A. (2012). Oil, erucic, and glucosinolate contents in winter hardy rapeseed germplasms. Industrial Crops and Products, 12, 33-38. https://doi.org/10.1016/S0926-6690(99)00043-6

Bond, J. J., Can, L. A., \& Warner, R. D. (2004). The effect of exercise stress, adrenaline injection and electrical stimulation on changes in quality attributes and proteins in semimembranosus muscle of lamb. Meat Science, 68(3), 469-477. https://doi.org/10.1016/S0926-6690(99)00043-6

Brewer, M. S., Zhu, L. G., Bidner, B. D., Meisinger, J., \& McKeith, F. K. (2001). Measuring pork color: Effects of bloom time, muscle, $\mathrm{pH}$ and relationship to instrumental parameters. Meat Sci., 57, 169-176. https://doi.org/10.1016/S0309-1740(00)00089-9

Byers, F. M., \& Schelling, G. T. (1993). Lipid in ruminant nutrition. In D. C. Church (Ed.), Ruminant Animal: Digestive Physiology and Nutrition (pp. 298-312). Prospect Heights, Waveland Press Inc., IL.

CIE (Commission Internationale de l'E A clairage). (1978). Recommendations on uniform color spaces-color difference equations. Psychometric Color Terms. Supplement No. 2 to CIE Publication No. 15 (E-1.3.1.) 1978, 1971/(TC-1-3). Commission Internationale de l'E A clairage, Paris.

Daszkiewicz, T., Hnatyk, N., Dabrowski, D., Janiszewski, P., Janiszewski, P., Gukolek, A., ... Koba-Kowalczyk, M. (2015). A comparison of the quality of the Longissimus lumborum muscle from wild and farm-raised fallow deer (Dama dama L.). Small Rumin. Res., 129, 77-83. https://doi.org/10.1016/j.smallrumres.2015. 05.003

Devine, C. E., Lowe, T. E., Wells, R. W., Edwards, N. J., Hockins, E., ... Speck, P. A. (2006). Pre-slaughter stress arising from on-farm handling and its interactions with electrical stimulation on tenderness of lambs. Meat Science, 73, 304-312.

Font-i-Furnols, M., \& Guerrero, L. (2014). Consumer preference, behavior and perception about meat and meat products: An overview. Meat Science, 98, 361-371. https://doi.org/ 10.1016/j.meatsci.2014.06.025

Fraser, M.D., Speijers, M. H. M., Theobald, V. J., Fychan, R., \& Jones, R. (2004). Production performance and meat quality of grazing lambs finished on red clover, lucerne, or perennial ryegrass swards. Grass and Forage Science, 59, 345-356. https://doi.org/10.1111/j.1365-2494.2004.00436.x

Geay, Y., Bauchart, D., Hocquette, J. F., \& Culioli, J. (2001). Effect of nutritional factors on biochemical, structural and metabolic characteristics of muscles in ruminants, consequences on dietetic value and sensorial qualities of meat. Reprod. Nutr. Dev., 41, 1-26. https://doi.org/10.1051/rnd:2001101

Geesink, G, Sujang, S., \& Koohmaraie, M. (2011). Tenderness of pre- and post-rigor lamb longissimus muscle. Meat Sci., 88, 723-726. https://doi.org/10.1016/j.meatsci.2014.02.018

Goetsch, A., Merkel, R., \& Gipson, T. (2011). Factors affecting goat meat production and quality. Small Ruminant Research, 101, 173-181.

Granti, S., Angel, S., Akiri, B., Holzer, Z., Aharoni, Y., Orlov, A., \& Kanner, J. (2001). Effects of vitamin E supplementation on lipid peroxidation and color retention of salted calf muscle from a diet rich in polyunsaturated fatty acids. J. Agri. Food Chem., 49, 5951-5956. https://doi.org/10.1021/jf010459s

Holman, B. W. B., Ponnampalam, E. N., Van de Ven, R. J., Kerr, M. J., \& Hopkins, D. L. (2015). Lamb meat color values (HunterLab CIE and reflectance) are influenced by aperture size (5 mm v. $25 \mathrm{~mm})$. Meat Science, 100, 202-208. https://doi.org/10.1016/j.meatsci.2014.10.006

Hutchison, C. L., Mulley, R. C., Wiklund, E., \& Flesch, J. S. (2012). Effect of concentrate feeding on instrumental meat quality and sensory characteristics of fallow deer venison. Meat Science, 90, 801-806. https://doi.org/10.1016/j.meatsci.2011.11.018

Juarez, M., Aldai, N., López-Campos, O., Dugan, M. E. R., Uttaro, B., \& Aalhus, J. L. (2012). Beef texture and juiciness. In Y. H. Hui (Ed.), Handbook of meat and meat processing (pp. 177-206). Florida: CRC Press. https://doi.org/10.1201/b11479-13 
Kannan, G., Gadiyaram, K. M., Galipalli, S., Carmichael, A., Kouakou, B., Pringle, T. D., ...Gelaye, S. (2006). Meat quality in goats as influenced by dietary protein and energy levels, and postmortem aging. Small Rumin. Res., 61(1), 45-52. https://doi.org/10.1016/j.smallrumres.2005.01.006

Kannan, G., Lee, J., \& Kouakou, B. (2014). Chevon quality enhancement: Trends in pre and post-slaughter techniques. Small Rumin. Res., 121, 80-88.

Kim, G. D., Jeong, J. Y., Hur, S. J., Yang, H. S., Jeon, J. T., \& Joo, S. T. (2010). The relationship between meat color (CIE $\mathrm{L}^{*}$ and $\left.\mathrm{a}^{*}\right)$, myoglobin content, and their influence on muscle fiber characteristics and pork quality. Korean Journal for Food Science of Animal Resources, 30, 626-633. https://doi.org/10.5851/kosfa. 2010.30.4.626

Kosulwat, S., Greenfield, H., \& James, J. (2003). Lipid composition of Australian retail lamb cuts with differing carcass classification characteristics. Meat Science, 65, 1413-1420. https://doi.org/10.1016/S0309-1740(03) 00064-0

Ledward, D. A. (2006). Metmyoglobin formation in beef muscles as influenced by water content and anatomical location. Journal of Food Science, 36(1), 138-140. https://doi.org/10.1111/j.1365-2621.1971.tb02055.x

Linares, M. B., Bórnez, R., \& Vergara, H. (2008). Effect of stunning systems on meat quality of Manchego suckling lamb packed under modified atmospheres. Meat Science, 78(3), 279-287.

Mancini, R. A, \& Hunt, M. C. (2005). Current research in meat color. Meat Sci., 71, 100-121. https://doi.org/ 10.1016/j.meatsci.2005.03.003

Muchenje, V., Dzama, K., Chimonyo, M., Strydom, P. E., Hugo, A., \& Raats, J. G. (2009). Some biochemical aspects pertaining to beef eating quality and consumer health: A review. Food Chemistry, 112, 279-289. doi:10.1016/j.foodchem.2008.05.103

Parodi, P. W. (2016). Dietary guidelines for saturated fatty acids are not supported by the evidence. Int. Dairy J., 52, 115-123. https://doi.org/10.1016/j.idairyj.2015.08.007

Periera, L., Pires, A. J. V., Carvaalho, G. G. P., Silva, R. V. M. M., Simionato, J. I., Lacerda, E. C. Q, .. Carvalho, B. M. A. (2016). Nutritional characteristics of lamb meat fed diets with cotton cake. J. Food Qual., 39, 140-149.

Perry, D., Thompson, J. M., Hwang, I. H., Butchers, A., \& Egan, A. F. (2001). Relationship between objective measurements and taste panel assessment of beef quality. Australian Journal of Experimental Agriculture, 41(7), 981-989. https://doi.org/10.1071/EA00023

Rhee, K. S. (1992). Fatty acids in meats and meat products. In C. K. Chow (Ed.), Fatty Acids in Foods and Their Health Implications (pp. 65-93). Marcel Dekker, New York.

Rhee, K. S., Waldron, D. F., Ziprin, Y. A., \& Rhee, K. C. (2000). Fatty acid composition of goat diets vs intramuscular fat. Meat Science, 54, 313-318. https://doi.org/10.1016/S0309-1740(99)00094-7

SAS, (2013). Statistical Analytical System. SAS Institute Inc., Cary, NC, USA.

Sheridan, R., Hoffman, L., \& Ferreira, A. (2003b). Meat quality of Boer goat kids and Mutton Merino lambs. 2. Sensory meat evaluation. Animal Science, 76, 73-79. https://doi.org/10.1017/S1357729800053327

Silva, T. M., de Medeiros, A. N., Oliveira, R. L., Gonzaga Neto, S., Queiroga, R. de C., Ribeiro, R. D., ... Bezerra, L. R. (2016). Carcass traits and meat quality of crossbred Boer goats fed peanut cake as a substitute for soybean meal. J. Anim. Sci., 94, 2992-3002. https://doi.org/10.2527/jas.2015-0131

Solaiman, S., Kerth, C., Willian, K., Min, B. R., Shoemaker, C., Jones, W., \& Bransby, D. (2011). Growth performance, carcass characteristics and meat quality of Boer-cross wether and buck goats grazing Marshall rye grass. Asian-Australasian Journal of Animal Sciences, 24, 351-357. https://doi.org/10.5713/ajas.2011. 10081

Tshabalala, P. A., Strydom, P. E., Webb, E. C., \& DeKock, H. L. (2003). Meat quality of designated South African indigenous goat and sheep breeds. Meat Science, 65, 563-570.

USDA. (1990). Composition of Foods. Beef Products: Raw, Processed, Prepared, Agric. Handbook 8-13. Human Nutritional Info. Serv., USDA, Washington D.C.

van Laack, R. L. J. M., \& Smulders, F. J. M. (1990). Color stability of bovine longissimus and psoas major muscle as affected by electrical stimulation and hot boning. Meat Science, 28(3), 211-221. https://doi.org/10. 1016/0309-1740(90)90005-Q 
Vergara, H., \& Gallego, L. (2000). Effect of electrical stunning on meat quality of lamb. Meat Science, 56(4), 345-349. https://doi.org/10.1016/S0309-1740(02)00049-9

Vergara, H., Linares, M. B., Berruga, M. I., \& Gallego, L. (2005). Meat quality in suckling lambs: Effect of pre-slaughter handling. Meat Science, 69(3), 473-478. https://doi.org/10.1016/j.meatsci.2004.09.002

Wardlow, F. R., McCaskill, L. H., \& Acton, J. C. (1973). Effects of post-mortem changes on poultry meat loaf properties. J. Food Sci., 38, 421-423. https://doi.org/10.1111/j.1365-2621.1973.tb01444.x

Webb, E. (2014). Goat meat production, consumption, and quality. Animal Frontier, 4, 33-37. https://doi.org/10. 2527/af.2014-0031

Webb, E. C., Casey, N. H., \& Simela, L. (2005). Goat meat quality. Small Ruminant Research, 60, $153-166$. https://doi.org/10.1016/j.smallrumres.2005.06.009

Wiklund, E., Stevenson-Barry, J. M., Duncan, S. J., \& Littlejohn, R. P. (2001). Electrical stimulation of red deer (Cervus elaphus) carcasses-Effects on rate of $\mathrm{pH}$-decline, meat tenderness, color stability and water-holding capacity. Meat Science, 59, 211-220. https://doi.org/10.1016/S0309-1740(01)00077-8

Wiklund, E., Manley, T. R., \& Littlejohn, R. P. (2004). Glycolytic potential and ultimate muscle pH values in red deer (Cervus elaphus) and fallow deer (Dama dama). RangiferDoi Rangifer, 24, 87-94. https://doi.org/10.7 $557 / 2.24 .2 .305$

Wood, J. D., Richardson, R. I., Nute, G. R., Fisher, A. V., Campo, M. M., Kasapidou, E., Sheard, P. R., \& Enser, M. (2003). Effect of fatty acids on meat quality: A review. Meat Science, 66, 21-32. https://doi.org/10.1016/ S0309-1740(03)00022-6

\section{Copyrights}

Copyright for this article is retained by the author(s), with first publication rights granted to the journal.

This is an open-access article distributed under the terms and conditions of the Creative Commons Attribution license (http://creativecommons.org/licenses/by/4.0/). 